\title{
METODY OCENY EFEKTYWNOŚCI DZIAtAŃ PRZEDSIĘBIORSTWA NA RZECZ KONSUMENTA NA PRZYKŁADZIE PRZEDSIĘBIORSTW INNOWACYJNYCH
}

lic. Damian Abramczyk Wydział Ekonomiczny, Uniwersytet Marii Curie-Skłodowskiej w Lublinie ORCID: https://orcid.org/0000-0002-2191-1378

\begin{abstract}
Streszczenie
Konsument dąży do tego by posiadać coraz więcej, poprzez wydatkowanie dochodu pozyskanego z różnych źródeł. Ten chce mieć więcej, niż mniej. Przedsiębiorstwa, chcąc sprostać oczekiwaniom klienta, produkują dobra, od jakości których zależy przyszły wynik finansowy przedsiębiorstwa. Klient, nabywając dobra od producenta oczekuje możliwie najwyższej jakości produktów, przy założeniu przeciętnego pułapu cenowego, dopasowanego względem jego preferencji oraz możliwości finansowych. Zdarzyć się może sytuacja, kiedy klient nie będzie zadowolony z usługi bądź produktu. Zdarzenie to wywołuje niekorzystny efekt na przedsiębiorstwo. Celem optymalizacji tego zjawiska niezbędne jest podjęcie działań zapobiegawczych, które prawie zawsze poprzedzone są wnikliwym badaniem i analizą. W poniższym artykule przedstawione będą wybrane przez autora metody pozyskania informacji o stopniu zadowolenia (satysfakcji) klienta z nabytych przez niego dóbr. Przytoczone zostaną argumenty społeczne oraz psychologiczne, mające wpływ na końcowy poziom satysfakcji klienta. Wskazane zostaną również skutki dla przedsiębiorstwa, związane z wynikami badania stopnia satysfakcji klienta.
\end{abstract}

Słowa kluczowe: jakość, satysfakcja, zadowolenie, produkt, usługa, klient, metoda NPS, badanie, ankieta, wywiad.

JEL Class: L15. 


\section{WSTĘP}

Nie podlega wątpliwości fakt, iż gospodarstwa domowe konsumują coraz więcej dóbr. Przedsiębiorstwa, stając naprzeciw oczekiwaniom klientów dokładają wszelkich starań, by produkować bądź dystrybuować więcej, by dobra niezbędne trafiały do ich nabywców. Proces produkcyjny definiowany jest jako szereg współistniejących ze sobą działań, związanych z przekształcaniem pozyskanych surowców (bądź półfabrykatów) w wyroby gotowe, pod wpływem innych zasobów przedsiębiorstwa [Błażewski 1970: 274]. Efektem końcowym procesu jest wytworzenie wartości dodanej w postaci wcześniej wspomnianego wyrobu gotowego, który następnie może zostać rozdystrybuowany do poszczególnych odbiorców, następnych ogniw łańcucha gospodarczego. Procesy biznesowe zachodzące w przedsiębiorstwie (definiowane jako ciągi następujących po sobie, bądź współistniejących jednocześnie, czynności, zmierzających do realizacji celu) wywołują określone zdarzenie gospodarcze, które przybliżają przedsiębiorstwo do osiągnięcia celu. Zdarzyć się jednak może, że nabywca dobra nie będzie zadowolony z nabytego asortymentu. Może to mieć związek z oferowaną przez producenta ceną, jakością (zarówno produktu/usługi, jak i obsługi sprzedażowej i posprzedażowej), nieodpowiednim stanem funkcjonalnym produktu, a także usterkami, wywołanymi błędami w procesie produkcyjnym. Dbając o potrzeby klientów niezbędne okazuje się przeprowadzanie badań jakości oferowanych dóbr, pod kątem występowania niekorzystnych dla przedsiębiorstwa zjawisk. W tym celu dokonywane są badania jakości. Celem niniejszego artykułu jest przedstawienie metod oceny satysfakcji klienta oraz oceny usługi/produktu pod kątem wprowadzenia potencjalnych korekt i modernizacji.

\section{DEFINICJA JAKOŚCI, NORMY JAKOŚCI ISO 9000/9001/9004 ORAZ 10000/10001}

Jakość jest wartością trudną do zdefiniowania. Nie jest możliwe wprowadzenie jednoznacznej, klarownej i oczywistej definicji jakości. Ta zmieniała się na przestrzeni wieków. Platon określał ją jako „pewien stopień doskonałości”, związany z wytwarzaniem dóbr bądź świadczeniem usług. Crosby określał ją jako zgodność efektu z określonymi wymaganiami. Według najnowszych norm, opracowanych przez Międzynarodową Organizację Normalizacyjną (International Organization for Standarization) jakością określa się zbiór inherentnych właściwości spełniających wymagania [www2, dostęp 28.06.2020]. Inna, również często przytaczana w literaturze definicja jakości dzieli ją na 5 rodzajów: 
1) postrzeganą - badaną na podstawie zmysłów oraz odczuć nabywców produktu;

2) opartą na produktach - ocena na podstawie przygotowanych projektów i prototypów, które następnie przekształcają się w finalne rozwiązania;

3) opartą na użytkownikach - ocena jakości na podstawie opinii konsumentów;

4) opartą na relacjach - ocena jakości na podstawie operacji - weryfikacja zgodności funkcjonalności ze specyfikacją techniczną produktu;

5) opartą na wartości - ocena jakości na podstawie ceny.

Pozyskanie odpowiednich certyfikatów usługi podnosi ogólną opinię na temat produktu, urzetelnia przedsiębiorstwo, stanowi ogromną szansę dla wdrażanej na rynku nowej usługi, szczególnie we wczesnych etapach cyklu życia produtu. W tym kontekście zalecane jest zwrócenie szczególnej uwagi na spełnienie oczekiwań i wymagań klientów, szczególnie tych nastawionych na pozyskiwanie innowacji. Certyfikatem świadczącym o wysokiej jakości oferowanych przez przedsiębiorstwo usług są między innymi normy ISO serii 9000 oraz ISO serii 10000 .

Seria certyfikatów ISO 9000 początkowo była wykorzystywana w przemyśle militarnym ze względu na konieczność zagwarantowania produktów sprawnych, kompletnych i niezagrażających życiu jednostek wojskowych, odpowiedzialnych za magazynowanie tychże materiałów militarnych. W skład serii ISO 9000 wchodzą między innymi:

- PN-EN ISO 9000:2015 System zarządzania jakością - Podstawy i terminologia;

- PN-EN ISO 9001:2015-10 System zarządzania jakością - Wymagania;

- PN-EN ISO 9004:2010 Zarządzanie mające na celu osiągnięcie trwałego sukcesu organizacji - Podejście przez zarządzanie jakością;

- PN-EN ISO 19011:2012 (U) Wytyczne dotyczące audytowania syste-mów zarządzania - zastępuje wersję z 2003 roku.

Kolejną grupą norm jakości jest seria norm ISO 10000, która jest wykorzystywana do zarządzania i pomiaru poziomu jakości w projektach realizowanych przez przedsiębiorstwa:

- ISO 10001, Customer satisfaction - Guidelines for codes of conduct;

- ISO 10002, Customer satisfaction - Guidelines for handling complaints; lution;

- ISO 10003, Customer satisfaction - Guidelines for external dispute reso-

- ISO 10004, Customer satisfaction — Guidelines for monitoring and measuring;

- ISO 10005, Guidelines for quality plans;

- ISO 10006, Guidelines for quality management in projects; 
- ISO 10008, Customer satisfaction — Guidelines for business-to-consumer electronic commerce transactions;

- ISO 10012, Guidance for the management of measurement processes;

- ISO/TR 10013, Guidelines for quality management system documentation;

- ISO 10014, Guidelines for realizing financial and economic benefits;

- ISO 10015, Guidelines for training;

- ISO 10017, Guidance on statistical techniques;

- ISO 10018, Guidelines on people involvement and competence;

- ISO 10019, Guidelines for the selection of quality management system consultants.

W niniejszym opracowaniu w szczególny sposób omówione zostaną normy PN-EN ISO 9001:2015-10, PN-EN ISO 9004:2010 oraz ISO 10001, które omawiają kwestie związane z zadowoleniem klienta, zarządzania jakością oraz wymagania dla przedsiębiorstwa ukierunkowanego na rozwój i wdrażanie innowacyjnych technologii.

Normę PN-EN ISO 9001:2015-10 mogą stosować wszystkie jednostki, bez względu na wielkość i rodzaj prowadzonej działalności. Standard określa minimalne wymagania wobec przedsiębiorstwa, celem zagwarantowania stabilnego systemu zarządzania jakością. Wymagania stawiane wobec przedsiębiorstwa dotyczą między innymi zasad sporządzania i obiegu dokumentacji, zachowania kierownictwa wobec metod zarządzania jakością, optymalizacji procesów biznesowych usprawniających produkcję oraz sprzedaż produktów bądź usług oraz weryfikację stopnia zadowolenia klienta ze zrealizowanych działań, świadczonych usług, sprzedanych produktów. Norma ta ukierunkowuje przedsiębiorstwo na zrozumienie potrzeb i oczekiwań konsumenta. $Z$ tego względu wymaga podejścia procesowego (identyfikowania oraz optymalizowania procesów nieefektywnych), opartego o cykl Deminga. kości:

Wymagania te realizują się przy uwzględnieniu tak zwanych ośmiu zasad ja-

1) zorientowanie na klienta;

2) przywództwo;

3) zaangażowanie kapitału ludzkiego;

4) podejście procesowe;

5) optymalizacja procesów poprzez zintegrowany system zarządzania jakością;

6) doskonalenie procesów biznesowych poprzez wykrycie i optymalizację procesów nieefektywnych;

7) rzeczowe podejście do podejmowania decyzji;

8) dbałość o dobre relacje z dostawcami. 


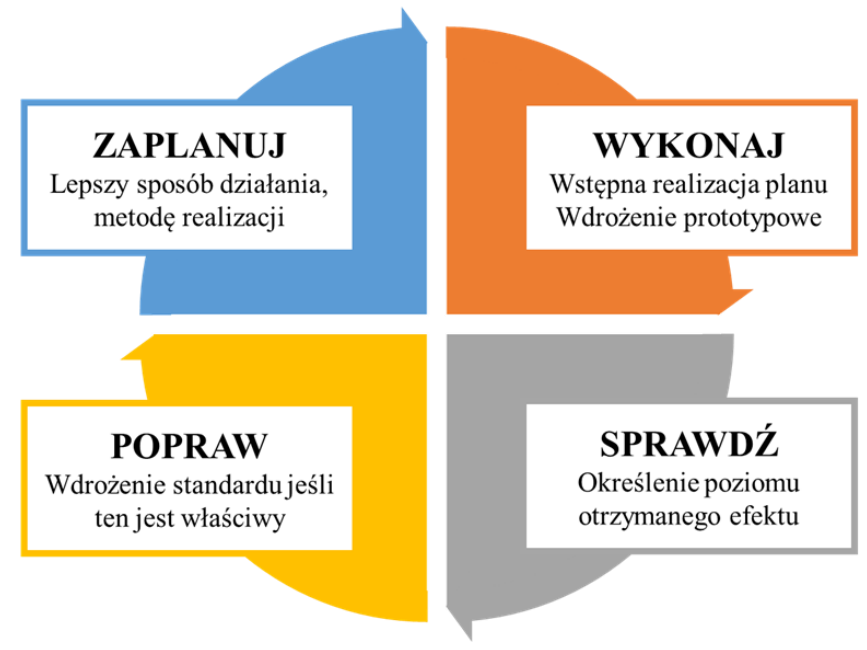

Rysunek 1. Plan-Do-Check-Act zwany również jako cykl Deminga

Źródło: opracowanie własne na podstawie Hamrol i Mantura 2006.

Rozszerzeniem normy PN-EN ISO 9001:2015-10 jest PN-EN ISO 9004:2010, zawierająca szczegółowe wytyczne dotyczące zarządzania organizacją poprzez zastosowanie nowoczesnego systemu zarządzania jakością. Podstawowym zadaniem przedsiębiorstwa certyfikowanego standardem PN-EN ISO 9004:2010 jest osiągnięcie celu poprzez zadowolenie wszystkich stron zainteresowanych transakcją, a więc z jednej strony przedsiębiorstwo innowacyjne, ukierunkowane na zysk oraz rozwój kluczowych dla niego kompetencji, a z drugiej konsumenta, celem dopasowania produktu usługi do nieustająco rosnących oczekiwań oraz standardów.

Norma ISO 10001 pozwala określić stopień zadowolenia klienta, metody jej ustalania oraz czy prowadzone działania marketingowe oraz organizacyjne ko-relują z potrzebami oraz oczekiwaniami klienta. Podobnie jak standardy serii 9000, normy serii 10000 mogą być wykorzystane we wszystkich organizacjach, mających na uwadze podniesienie satysfakcji klienta [www3, dostęp 28.06.2020]. Norma ta zawiera szczegółowe wytyczne dla organizacji z zakresu metod oraz technik badania zadowolenia klientów oraz kodeksów postępowania przedsiębiorstw względem nabywców usług. Norma ta ponadto zawiera przykłady elementów, składających się na techniki badania satysfakcji klienta. 


\section{METODY OCENY EFEKTYWNOŚCI DZIAŁAŃ PRZEDSIĘBIORSTWA WZGLĘDEM KONSUMENTA - OCENA SATYSFAKCJI I LOJALNOŚCI KLIENTA}

\subsection{Metoda NPS}

Jednym z najważniejszych czynników mających wpływ na rozwój przedsiębiorstwa oraz oferowanych przez niego produktów jest poziom lojalności jego klientów. Wierny klient stanowi gwarant przyszłych przychodów ze sprzedaży dla przedsiębiorstwa oraz poszerzenia strefy wpływów, co umożliwia dalszy rozwój firmy w różnych gałęziach gospodarki. Aby w sposób rzetelny zmierzyć wyżej wspomniany poziom lojalności klienta wobec marki, przedsiębiorstwa stosują różne metody analityczne. Jedną z nich, cieszącą się niegasnącą popularnością ze względu na niski koszt wdrożenia jest metoda NPS (Net Promoter Score), która umożliwia weryfikację opinii klientów na temat danego rozwiązania (produktu bądź usługi oferowanych przez przedsiębiorstwo).

Wartość wskaźnika NPS pozwala określić, jaką opinią cieszy się dane rozwiązanie wśród klientów marki. Wynik wskaźnika jest poniekąd prognozą przyszłego wyniku na sprzedaży firmy, bowiem od wysokiego stopnia lojalności klientów zależy zwiększenie przychodów z działalności operacyjnej. Wartość wskaźnika wyrażana jest w skali dwustustopniowej, wyrażonej co do wartości bezwzględnej. Maksymalna ujemna wartości wskaźnika (-100 pkt) i przedstawia złą kondycję marki na tle branży. Wraz ze wzrostem wartości NPS, rośnie także liczba promotorów, ambasadorów marki względem próby badanej - wartością maksymalną jest +100 punktów, co oznacza opinię niemal nieskazitelną. $W$ praktyce wartość wskaźnika NPS nigdy nie osiągnie wartości maksymalnej. Wartość NPS powyżej 50 punktów dla produktu bądź usługi jest oceniania przez ekspertów jako doskonała. W celu klarownego przedstawienia metody wskaźnikowej Net Promoter Score można posłużyć się niniejszą grafiką - zob. rysunek 2.

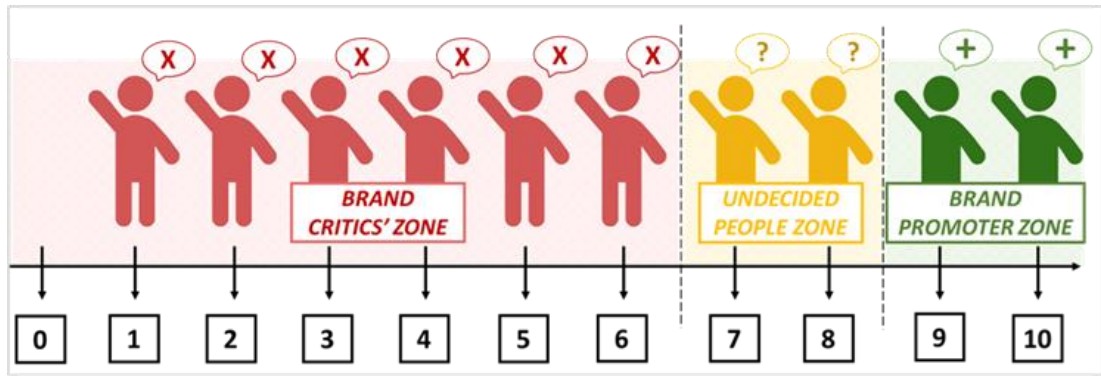

Rysunek 2. Schemat oceny satysfakcji metodą Net Promoter Score

Źródło: opracowanie własne. 
Zauważalny jest zdecydowanie większy wpływ krytyków marki, w porównaniu do jej promotorów. Niechęć do produktu bądź usługi wynika z naturalnej psychologicznej, ludzkiej skłonności do krytykowania, która z biegiem lat ulega zdecydowanemu pogorszeniu. To dobry sygnał dla przedsiębiorców, pragnących utrzymać jak największą liczbę klientów przy swoich produktach. Celem zobrazowania tego zjawiska posłużono się wynikami badań przeprowadzonymi przez Uniwersytet Humanistyczno-Społeczny oraz ARC Rynek i Opinia w 2019 roku. $\mathrm{Z}$ raportu wynika iż zdecydowanymi krytykującymi są mężczyźni (52\% badanych osób), najczęściej w wieku szkolnym (15-24 lata), posiadający profile w dominujących social media (Facebook, Instagram, Tweeter, YouTube). Zdecydowanie większą skłonnością do krytykowania cechują się internauci (55\% badanych). W przeprowadzonym badaniu zapytano także o stosunek ankietowanych do wyrażania niepochlebnych opinii $\mathrm{w}$ Internecie. $Z$ raportu wynika, iż zdania są podzielone - na pytanie, czy ankietowany wyraża się krytycznie w Internecie, dokładnie taka sama liczba ankietowanych odpowiedziała przecząco, jak i twierdząco [SWPS \& ARC]. Wyniki tego badania zostały przedstawione na poniższym zestawieniu zob. wykres 1 .

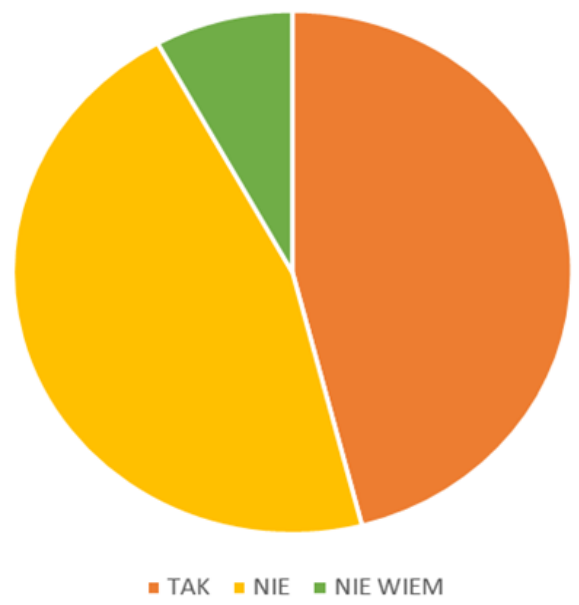

Wykres 1. Zdanie społeczeństwa co do wyrażania krytycznych opinii w Internecie Źródło: www1, dostęp 28.06.2020. 
Tabela 1 przedstawia opis poszczególnych grup lojalności wobec marki.

Tabela 1. Możliwe scenariusze klientów podczas oceny metodą Net Promoter Score

\begin{tabular}{|c|c|}
\hline 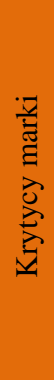 & $\begin{array}{l}\text { - Są to przede wszystkim klienci w pewnym stopniu niezadowoleni z usług } \\
\text { świadczonych przez przedsiębiorstwa. } \\
\text { - Zdaniem krytyków marki, świadczone przez przedsiębiorstwo usługi odbiegają } \\
\text { w sposób znaczny od standardów jakości bądź poziomu kosztów. } \\
\text { - Krytycy marki nigdy bądź prawie nigdy nie powrócą do marki krytykowanej. } \\
\text { - Krytycy marki mogą przyczynić się do spadku efektywności promocji } \\
\text { innowacyjnych rozwiązań. } \\
\text { - Krytycy marki zdecydowanie częściej będą odradzać skorzystanie z marki niż } \\
\text { promotorzy będą ją polecali. Wynika to z naturalnych skłonności społeczeństwa do } \\
\text { negatywnych opinii, w dużej mierze nacechowanych emocjonalnie. }\end{array}$ \\
\hline 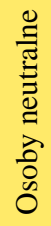 & $\begin{array}{l}\text { - Klienci neutralni nie wpływają na sprzedaż ani pozytywnie, ani negatywnie - nie } \\
\text { powodują strat z tytułu zniechęcenia do marki, ani nie zachęcają kolejnych } \\
\text { odbiorców do skorzystania z usługi/ zakupu produktu. }\end{array}$ \\
\hline 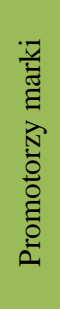 & $\begin{array}{l}\text { - Klienci utożsamiają się z daną marką, pragną, aby coraz większa część ich } \\
\text { bezpośredniego otoczenia nabywała produkty i usługi firmy. } \\
\text { - Klienci niemal zawsze wracają do marki ze względu na przywiązanie, zadowalające } \\
\text { standardy jakości, przystępną cenę. } \\
\text { - Klienci stają się, ,ambasadorami marki” ze względu na jakość oferowanych } \\
\text { produktów bądź usług. } \\
\text { - Promotorzy pełnią istotną rolę podczas poszerzania oferty świadczonych produktów } \\
\text { bądź usług. }\end{array}$ \\
\hline
\end{tabular}

Źródło: opracowanie własne na podstawie: www4, dostęp 28.06.2020.

Dla każdej z przedstawionych grup przedstawia się także ogólne oraz szczegółowe zalecenia, których wykonanie może w przyszłości przesądzić o dalszym postrzeganiu marki.

1) Krytycy marki - Zaleca się zwrócenie szczególnej uwagi pod kątem wystąpienia zjawisk niepożądanych - w tym spadku przychodów ze sprzedaży usług innowacyjnych.

2) Osoby neutralne - Zaleca się zwrócenie szczególnej uwagi na grupę osób neutralnych, celem zachęcenia ich do skorzystania $\mathrm{z}$ usług i pozostania wiernym marce. Potrzeby konsumenta nieustannie się zmieniają. 
3) Promotorzy marki - Zaleca się dalszy rozwój marki, pod kątem dostosowania funkcjonalności produktu bądź usługi do nieustannie zmieniających się (i rosnących) potrzeb konsumentów.

Wskaźnik NPS przedstawia procentową ilość promotorów do procentowej ilości krytyków. Jest on przedstawiony jako różnica procentowej liczby promotorów marki oraz krytyków marki. W ocenie wskaźnikowej udział osób neutralnych jest pomijany.

$$
\text { NPS }=\% \text { PROMOTORÓW }-\% \text { KRYTYKÓW }
$$

Wskaźnik NPS umożliwia zespołom analitycznym określenie stopnia lojalności klientów wobec marki oferowanej przez dane przedsiębiorstwo. Net Promoter Score określa się jako efektywną technikę pozwalającą na oszacowanie poziomu zainteresowania produktem, podjęcie decyzji dotyczącej dalszego rozwoju produktu/usługi. Przedsiębiorstwu bowiem zależy na pozyskaniu klientów lojalnych, chętnych do propagowania marki w swoim najbliższym otoczeniu. Do zalet metody oceny efektywności wskaźnika NPS zaliczyć można między innymi:

- zrozumienie oczekiwań klienta wobec danego produktu/usługi;

- weryfikację zapotrzebowania na dany produkt bądź usługę;

- wskazanie zalet oraz wad oferowanych rozwiązań;

- niskie koszty przeprowadzenia badania;

- otrzymanie subiektywnej opinii klientów na temat produktów/ usług.

- udoskonalenie metod wsparcia klienta, zwłaszcza w usługach posprzedażowych.

\subsection{Metoda SERVQUAL}

Celem określenia poziomu jakości świadczonych wobec klienta usług możliwe jest także oszacowanie poziomu jego zadowolenia. Metoda SERVQUAL pozwala w sposób punktowy oszacować wartość wywiązywania się pracowników ze swoich obowiązków względem klienta. Miernikiem poziomu satysfakcji klienta są między innymi :

- niezawodność pracowników obsługujących klienta - której wyrazem jest dostarczenie kompletnej i jakościowej usługi bądź produktu;

- odpowiedzialność za nabywcę, umiejętność elastycznego dopasowania się do sytuacji, natychmiastowa reakcja na oczekiwania i potrzeby klienta;

- empatia wobec klienta - konieczna w procesie nabywania przez konsumenta, celem jego zatrzymania i dostosowania się do jego potrzeb i oczekiwań; 
- zaufanie, budowane poprzez pewność pracowników - umiejętność pozyskania przychylnej opinii klienta poprzez wiedzę na temat oferowanych produktów/usług oraz zasady kindersztuby;

- dostępność zasobów niezbędnych do realizacji zlecenia w oparciu o zasadę namacalności - klient powinien czuć wprowadzone w przedsiębiorstwie udogodnienia, móc dostrzec interesujący go produkt, mieć możliwość zapoznania się z ofertą sklepu, doświadczyć różnych bodźców na niego oddziałujących [www5, dostęp 27.06.2020; Snarski 2012].

W tym celu przedsiębiorstwo opracowuje odpowiedni kwestionariusz, wyrażony w skali punktowej, zazwyczaj od 1 do 7 punktów.

Metoda SERVQUAL bazuje na stwierdzeniach, przypisanych do wyżej wymienionych cech. Opracowany przez przedsiębiorstwo kwestionariusz powinien zawierać 22 stwierdzenia, których analiza umożliwi poznanie kompletnej opinii klienta na temat realizowanej usługi, nabytym produkcie bądź świadczonej obsłudze (sprzedażowej bądź posprzedażowej). Klient otrzymuje kwestionariusz zawierający pytania, na które udziela subiektywnych odpowiedzi, w zależności od jego odczuć związanych ze zrealizowaną usługą. Udzielenie przez ankietowanego odpowiedzi o najniższej wartości (1) oznacza, że pracownik nie wywiązał się ze swojego obowiązku, usługa nie była świadczona na możliwie najwyższym poziomie, a sam proces sprzedaży określa się jako nieefektywny. Wówczas konieczna jest zmiana w tym obszarze. Z kolei ocena najwyższa określa usługę jako rzetelną, wykonaną pieczołowicie, $\mathrm{z}$ dołożeniem wszelkich starań, aby klient otrzymał produkt kompletny w możliwie najkrótszym czasie.

Poprzez zastosowanie metody SERVQUAL możliwe stało się dokonanie predykcji zdarzeń, związanych z utrzymaniem się innowacyjnej usługi/produktu na rynku. Odpowiednio wczesne wykrycie nieprawidłowości umożliwia przedsiębiorstwu dokonanie niezbędnych modyfikacji.

Poziom satysfakcji metodą SERVQUAL jest mierzony za pomocą:

$$
\mathrm{S}=\sum(\mathrm{P}-\mathrm{O})
$$

$\mathrm{S}$ - spełnienie oczekiwań klientów;

$\mathrm{O}$ - oczekiwana jakość realizowanej usługi,

$\mathrm{P}$ - postrzegana przez klientów jakość obsługi.

Opracowanie metody SERVQUAL pozwoliło na przygotowanie pięciu możliwych do spełnienia scenariuszy (tak zwanych luk jakości), które w przyszłości mogą wpływać negatywnie na postrzeganie świadczonych usług, produktu, a w konsekwencji obraz przedsiębiorstwa jako całości. 
Wspomniane luki, scenariusze, które mogą potencjalnie obniżyć poziom atrakcyjności mogą obejmować między innymi:

- różnica między oczekiwaniami zarządu przedsiębiorstwa a oczekiwaniami konsumentów;

- rozbieżność między postrzeganiem funkcjonalności usługi przez kierownictwo a realną specyfikacją produktu/usługi;

- rozbieżność między specyfikacją usługi a metodą jej realizacji;

- rozbieżność komunikacyjna pomiędzy producentem a konsumentem;

- rozbieżność między postrzeganiem usługi przez klienta a jego oczekiwaniami co do produktu finalnego.

Tabela 2 przedstawia przykładowe pytania, weryfikujące poziom jakości metodą SERVQAL.

Tabela 2. Przyjęty do analizy SERVQUAL model badania (ankieta)

\begin{tabular}{|c|c|}
\hline & PROPONOWANE PYTANIA \\
\hline \multirow{4}{*}{ 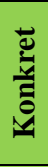 } & Czy przedsiębiorstwo oferuje sprzęt nowoczesny, innowacyjny? \\
\hline & Czy obiekty oferowane przez przedsiębiorstwo są atrakcyjne dla klienta? \\
\hline & Czy prezencja pracowników przedsiębiorstwa sprzyja zakupie usług/produktów? \\
\hline & Czy oferowane materiały promocyjne są atrakcyjne dla klienta? \\
\hline \multirow{5}{*}{ 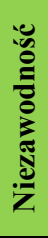 } & Czy przedsiębiorstwo dotrzymuje słowa? \\
\hline & Czy przedsiębiorstwo pomaga Ci rozwiązać problem, jeśli zachodzą nieprawidłowości? \\
\hline & $\begin{array}{l}\text { Czy przedsiębiorstwo realizuje usługę/sprzedaje produkt zgodnie ze wszelkimi } \\
\text { standardami jakości? }\end{array}$ \\
\hline & Czy przedsiębiorstwo terminowo wywiązuje się ze swoich zobowiązań? \\
\hline & Czy przedsiębiorstwo prowadzi rzetelną i bezbłędną dokumentację? \\
\hline \multirow{4}{*}{ 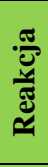 } & Czy pracownicy informują o terminie realizacji zlecenia? \\
\hline & Czy pracownicy szybko reagują i realizują zlecenia? \\
\hline & Czy pracownicy są chętni do pomocy? \\
\hline & Czy pracownicy mają czas, aby pomóc klientowi? \\
\hline \multirow{4}{*}{ 兑 } & Czy pracownicy są godni zaufania? \\
\hline & Czy nabywając produkt/usługę przedsiębiorstwa czujesz się bezpieczny? \\
\hline & Czy pracownicy są dobrze wychowani i uprzejmi? \\
\hline & Czy pracownicy są kompetentni? \\
\hline \multirow{5}{*}{ 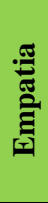 } & Czy pracownik zwraca uwagę na klienta? \\
\hline & Czy godziny obsługi klienta są dla niego dogodne? \\
\hline & Czy przedsiębiorstwo dysponuje pracownikami z indywidualnym podejściem do klienta? \\
\hline & Czy pracownik kieruje się interesem klienta? \\
\hline & Czy pracownik rozumie potrzeby klienta? \\
\hline
\end{tabular}

Źródło: opracowanie własne na podstawie Snarski 2012. 


\subsection{Metoda CSI}

W celu weryfikacji satysfakcji klientów powszechnie stosowaną metodą jest wykorzystywanie wskaźnika CSI (Customer Satisfaction Index). Technika ta wydaje się pozornie łatwa, bowiem polega jedynie na obliczeniu wskaźnika. Niezbędne jednak jest pozyskanie informacji, jakich dostarczają zaawansowane badania marketingowe.. Pozwalają one przede wszystkim zobrazować sytuację analitykom w związku z ocenianą grupą badawczą.

Analiza ta odnosi się do wielu sfer i obejmuje pewne czynniki - to wszystko znacząco wpływa na kształtowanie poziomu satysfakcji konsumenta. Należą do nich jakość usług, kanały dystrybucji czy polityka obsługi klienta. Nie mniej ważna okazuje się polityka marketingowa oraz cenowa prowadzona przez przedsiębiorstwo. W celu przeprowadzenia prawidłowego i wnikliwego procesu analizy, zarząd przedsiębiorstwa może oprzeć swoje działania na poradach eksperckich. Ułatwia to ocenę i wpływ powyższych czynników na daną usługę. Warto jednak zwrócić uwagę, że subiektywna ocena konsumentów to najlepszy głos doradczy, dlatego szczególną uwagę należy skupić na proces przeprowadzenia wywiadu z klientem. W tym celu tworzony jest specjalny formularz oceny konsumenta, który powinien zawierać pytania z zakresu wspomnianych wcześniej czynników korelujących z satysfakcją klienta. Każde pytanie w formularzu opinii ma odpowiednią, dziesięciostopniową skalę oceny. Poprzez średnią wyłaniającą się z zebranych od klientów opinii, wylicza się wskaźnik CSI:

$$
\mathrm{CSI}=\sum\left(\frac{\text { pytanie } 1+\text { pytanie } 2+\ldots+\text { pytanie } X}{X}\right)
$$

przy czym $X$ to maksymalna liczba pytań przeprowadzona w badaniu.

Właściwe określenie poziomu wskaźnika CSI wraz z cyklicznym powtarzaniem pomiarów pozwoli na zwiększenie dokładności analizy, co przełoży się na właściwy stopień zadowolenia klientów. Pytania zawarte w ankiecie nie mogą zatem być modyfikowane, ze względu na ułatwienie zestawienia $\mathrm{z}$ poprzednimi okresami oraz określenie linii trendu satysfakcji z usług. Tak zastosowany mechanizm zapewni sprawną realizację procesów decyzyjnych i marketingowych przedsiębiorstwa.

\subsection{Metoda IDI}

Jedną z technik pozyskiwania rzetelnych i wnikliwych informacji dotyczących świadczonych przez przedsiębiorstwo usług oraz poziomu zadowolenia konsumentów, jest pogłębiony wywiad z klientem IDI. Pozwala on na realną ocenę poziomu świadczonych usług. 
Na potrzeby realizacji powyżej opisanej analizy wykorzystuje się opracowaną wcześniej ankietę, której szeroka gama tematów okazuje się elementem koniecznym przy weryfikacji poziomu satysfakcji z usług. Technika pogłębionego badania, w opozycji do tradycyjnych metod, skupia się głównie na swobodnej wypowiedzi respondenta. Zadaniem oceniającego jest prowadzenie rozmowy, aby uzyskać jednoznaczne odpowiedzi na pytania w różnych obszarach tematycznych. Wydłuża to zdecydowanie czas przeprowadzania badania pogłębionego - ten może wynieść nawet godzinę.

Ocena poziomu satysfakcji klienta zgodnie z przyjętą metodą IDI skupia się wokół subiektywnych wrażeń i emocji konsumenta, związanych z świadczoną usługą, ogólnymi wrażeniami, przemyśleniami.

Rzetelne oraz jednoznaczne wyniki zapewni pogłębiona metoda kontaktu z klientem. Te należy przeprowadzać szczególnie, gdy:

- ze względu na złożoność produktu/usługi niemożliwe jest pozyskanie wiarygodnej próby badawczej - opinie są trudnodostępne;

- istnieje grono eksperckie, które mogłoby również wypowiedzieć się na temat produktu usługi;

- tematyka badania obejmuje kwestie wrażliwe, intymne, mogące naruszyć poczucie bezpieczeństwa respondenta;

- oczekuje się wielu wniosków, popartych argumentami emocjonalnymi.

$\mathrm{W}$ efekcie otrzymuje się rzetelne oraz kompletne wyniki przeprowadzonego badania. Ich interpretacja pozwoli na ocenę motywów działania klienta, jego cech, usposobienia oraz zmian $\mathrm{w}$ jego najbliższym otoczeniu.

\section{ZACHOWANIA KONSUMENTA I ICH WPŁYW NA JEDNOSTKĘ GOSPODARCZA}

\subsection{Zachowania konsumenta - lojalność wobec marki}

Zadowolenie klienta można wyrazić za pomocą zależności poziomu satysfakcji oraz prawdopodobieństwa przywiązania do marki (lojalności). Zależność ta ma charakter wykładniczy i może zostać przedstawiona w postaci graficznej - zob. rysunek 3.

Kolejną metodą oceny stopnia zadowolenia klienta jest stosunek między oczekiwaniami klient, a realnie świadczoną usługą. Jeśli oczekiwania te były większe niż otrzymany efekt - wówczas klient jest niezadowolony z usługi (istnieje ryzyko, że klient stanie się krytykiem marki), jeśli oczekiwania i efekt pokrywają się - klient jest zadowolony z usługi, jeśli efekt przerósł oczekiwania klient jest bardzo zadowolony, a więc istnieje bardzo duże prawdopodobieństwo przywiązania do marki w przyszłości. 


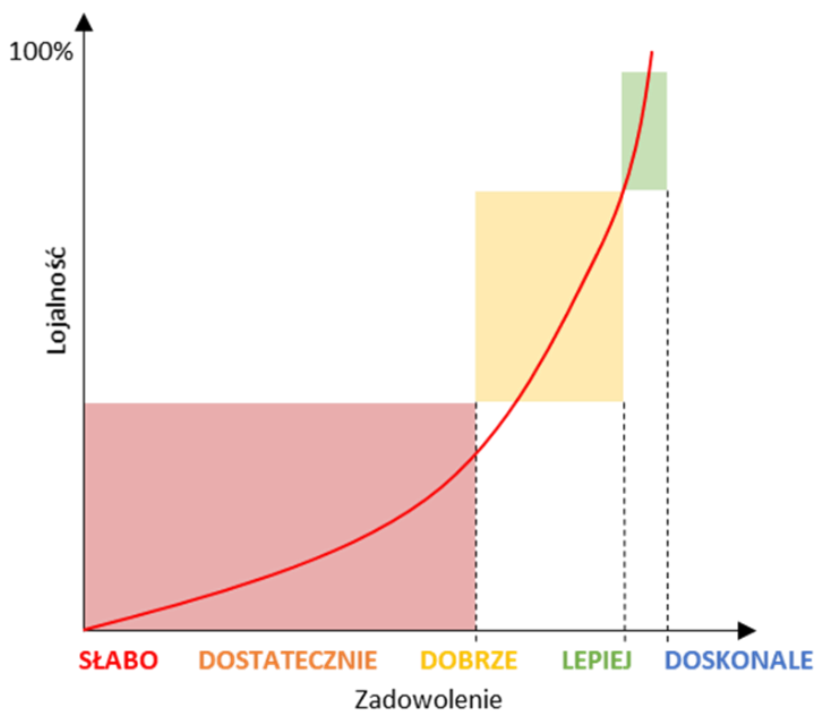

Rysunek 3. Wykres zależności lojalności od stopnia zadowolenia klienta z oferowanego dobra

Źródło: opracowanie własne.

Literatura przedmiotu definiuje czynniki wywierające szczególny wpływ na oczekiwania klienta. Są to przede wszystkim:

- czynniki osobiste - indywidualne cechy klienta, jego nastawienie, poglądy, przekonania, upodobania, gust;

- doświadczenia klienta - przebyte doświadczenia (negatywne bądź pozytywne) z daną marką, produktem bądź usługą. Do grupy czynników zalicza się również przywiązanie do marki, lojalność wobec produktów;

- forma przekazu informacji - literatura określa dwa podstawowe kanały przekazu informacji - formalny i nieformalny. W przypadku nieformalnych metod przekazu informacji, oczekiwania będą kreowane na podstawie przekazów ustnych, zawierających subiektywną opinię klientów i ich bezpośredniego otoczenia. W przypadku metod formalnych, oczekiwania mogą być kreowane przez przekazy przedsiębiorstwa, reklamy, broszury i ulotki informacyjne.

- ukryte przekazy informacyjne - niedostrzegalne na pierwszy rzut oka. Są to między innymi wygląd fizyczny, innowacyjne rozwiązania w prowadzonej kampanii marketingowej, wygląd budynków. Klient dostrzegając zmiany w przedsiębiorstwie oczekuje także zmian w oferowanych produktach. 
Oczekiwania klientów mają wiele źródeł (zob. tabela 3).

Tabela 3. Wskazane podczas analizy czynniki mające wpływ na oczekiwania klientów źródła oczekiwań klientów

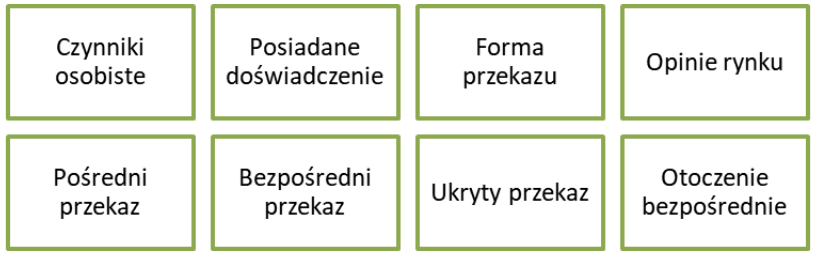

Źródło: opracowanie własne.

Wskazane w niniejszym opracowaniu zagadnienia skupiają się na utrzymaniu odpowiednio wysokiego stopnia lojalności klienta wobec marki, co ma bezpośrednie przełożenie na przyszłe wyniki finansowe jednostki. Przedsiębiorstwo zorientowane na klienta może w każdej chwili dokonać różnych ocen spełnienia poziomu satysfakcji. Wykorzystanie odpowiednich metod nie wyklucza się - możliwe jest wykorzystanie wszystkich możliwych narzędzi, umożliwiających dokładny pomiar poziomu oczekiwań klienta, jednak ze względu na specyfikę branży zalecane jest indywidualne podejście do przedsiębiorstwa, które ma zostać poddane badaniu. Zaleca się ponadto skorzystanie z wykwalifikowanych jednostek doradczych, specjalizujących się w marketingu bądź innych organizacji, takich jak Instytucje Otoczenia Biznesu, których zadaniem jest odpowiednie zorientowanie firmy na klienta, a w konsekwencji na zysk z działalności operacyjnej. Związek między poziomem zadowolenia klienta a przyszłymi zyskami podmiotu gospodarczego może zostać przedstawiony w postaci graficznej - zob. rysunek 4.

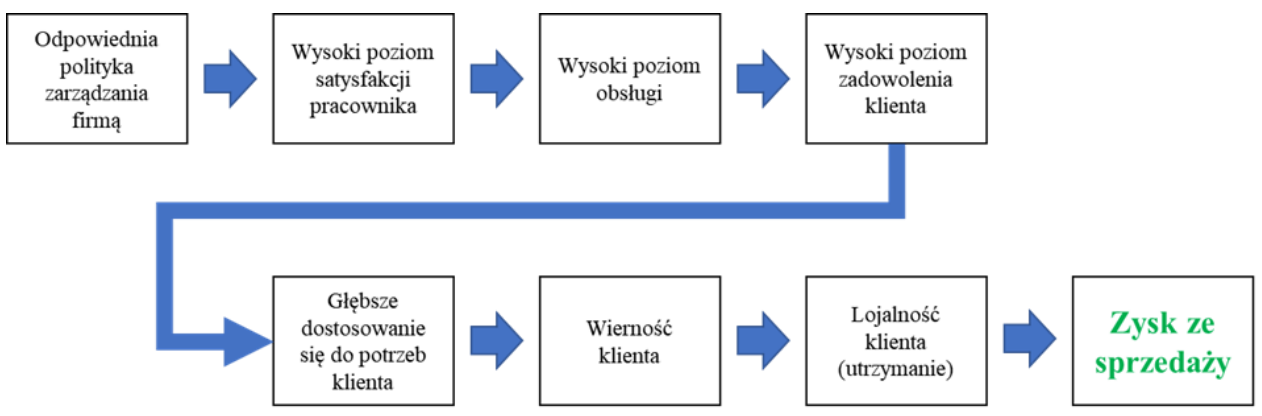

Rysunek 4. Zależność między poziomem satysfakcji a przyszłym przechodem z działalności operacyjnej

Źródło: opracowanie własne na podstawie Huczek 2013. 
Utrzymanie odpowiednio wysokiego poziomu zadowolenia klienta ma więc charakter długoterminowy. $Z$ tego względu zdecydowanie rekomendowane jest cykliczne wykonywanie testów poziomu satysfakcji, ze szczególnym uwzględnieniem przedmiotu prowadzonej działalności.

\subsection{Wpływ oceny satysfakcji na decyzje gospodarcze jednostki na przykładzie wybranych przedsiębiorstw}

\subsubsection{BRANŻA KOSMETOLOGICZNA - MEDYCYNA ESTETYCZNA}

Badanie satysfakcji klientów ma za zadanie wykazać mocne strony oferowanego produktu, usługi bądź obsługi klienta. Zdarzyć się może, że ocenie satysfakcji podlegają nie tylko czynniki bezpośrednio powiązane $z$ realizowaną odpłatnie czynnością, lecz także otoczenie oferowanej usługi. W przypadku medycyny estetycznej, klientki (a także coraz więcej klientów) przywiązują szczególną uwagę do sterylności otoczenia, jego wystroju, towarzyszącej zabiegom muzyki oraz innych, często niedocenianych obszarów usługi.

Badanie przeprowadzone przez M. Ankiel oraz A. Kuczyńską skupiło się wokół obszarów stanowiących mocne strony branży kosmetycznej oraz determinantów oceny zrealizowanej usługi medycyny estetycznej, co w konsekwencji spowodowało wybór odpowiedniej placówki medycznej. Badanie to umożliwiło przedstawienie kanałów kontaktu z klientami oraz określenie stopnia zadowolenia z obsługi oraz określenie obszarów szczególnie zachęcających klientki do ponownego skorzystania $\mathrm{z}$ oferowanych usług. $\mathrm{Na}$ analizie tych drugich skupiono się w niniejszym opracowaniu.

Podczas przeprowadzanego badania posłużono się opisywaną w opracowaniu metodą pogłębionego wywiadu z klientem. Zdaniem badanych, najistotniejszym czynnikiem, mającym kolosalny wpływ na końcowe postrzeganie usługi, był sam sposób przeprowadzenia zabiegu oraz efekt końcowy. 87 na 100 respondentów określa efekt końcowy jako główny determinant satysfakcji z przeprowadzonej usługi. Nie jest to niespodzianką - klienci oczekują efektu w postaci otrzymanego produktu bądź zmiany po zrealizowanej usłudze - wówczas mogą podejmować decyzje o ponownym skorzystaniu z usługi i poleceniu go następnym ogniwom łańcucha gospodarczego - swoim bliskim i rodzinie, bądź podzielić się opinią za pomocą mediów społecznościowych. Podczas badania szczególną uwagę zwrócono także na atmosferę towarzyszącą klientom podczas wykonywania zabiegu. Zdaniem 79\% wszystkich respondentów odpowiednie przygotowanie i przeprowadzenie usługi w sprzyjającej atmosferze umożliwia klientom odstresowanie się i rozluźnienie mięśni, które mogą zostać poddane zabiegowi medycyny estetycznej. 
Niemal równie istotne znaczenie przypisuje się do urządzeń oraz wykorzystanych podczas zabiegów preparatów - odpowiednio $77 \%$ oraz $75 \%$ badanych przyznaje, że wykorzystanie materiałów oraz urządzeń najwyższej jakości sprzyja odstresowaniu i finalnemu podwyższeniu oceny przeprowadzonej usługi. Dla medycyny estetycznej czynnik ten ma szczególne znaczenie, ze względu na ingerencję lekarza w ciało klienta, co stwarza zagrożenie infekcji, zniekształceń bądź braku zadowolenia z usługi, której poprawienie może nie okazać się proste bądź nawet możliwe [Ankiel i Kuczyńska 2017].

\subsubsection{BRANŻA UBEZPIECZENIOWA}

Innym przykładem zastosowania wyżej wymienionych metod oceny satysfakcji klienta jest branża ubezpieczeniowa, w której to zastosowano badanie metodą SERVQUAL. Podmiot wykonujący badanie satysfakcji skupił obszar swojego zainteresowania wokół klientów zakładów ubezpieczeniowych zrzeszonych na terenie województwa warmińsko-mazurskiego. Otrzymane podczas badania opinie zostały przedstawione w trzech niezależnych ujęciach:

- kanał dystrybucji możliwy do wyboru w przyszłości,

- kanał dystrybucji wykorzystywany w trakcie przeprowadzania badania,

- minimalny poziom satysfakcji z oferowanych przez firmę ubezpieczeniową usługi.

Badanie to, choć przeprowadzone w 2007 roku, umożliwia bardzo klarowne zaprezentowanie istoty oceny satysfakcji za pomocą metody SERVQUAL. Zgodnie z założeniami metody SERVQUAL, osoba poddawana badaniu została poproszona o przyporządkowanie do każdej z wymienionej cechy odpowiedniej wagi wartości punktowej od 1 do 7 , gdzie 7 stanowiło czynnik wyjątkowo ważny.

Podczas badania określono stopień istotności cech dla wyżej wspominanych ujęć. Podczas analizy skupiono się na cechach takich jak:

1) materialność usługi ubezpieczeniowej,

2) niezawodność osoby wykonującej usługę,

3) reakcja agenta ubezpieczeniowego na oczekiwania klienta,

4) fachowość agenta ubezpieczeniowego,

5) empatia agenta ubezpieczeniowego wobec klienta.

Przeprowadzenie badania umożliwiło opracowanie poziomów istotności cech dla klientów firmy ubezpieczeniowej. Te zostały przedstawione na poniższym zestawieniu - zob. wykres 2. 


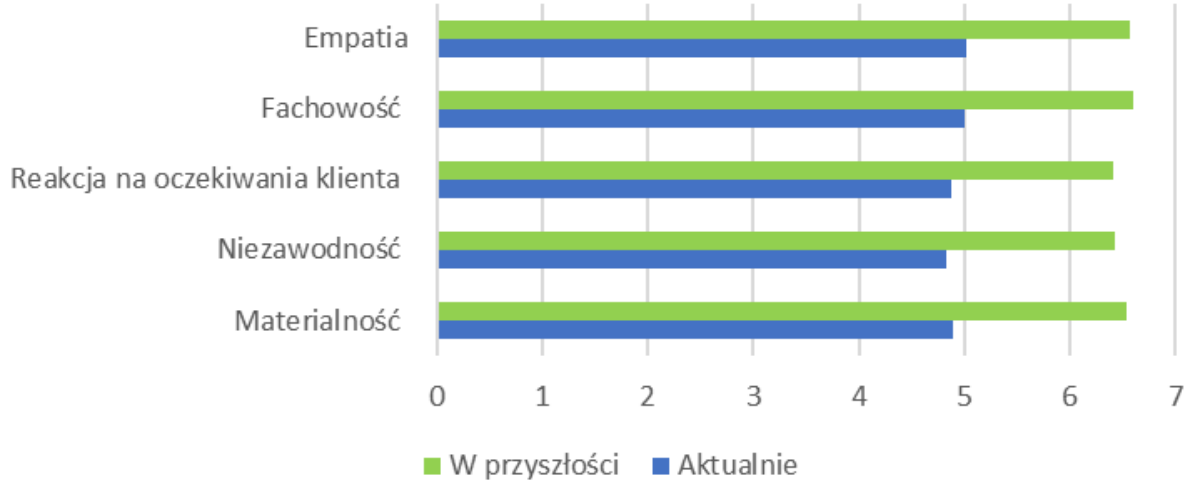

Wykres 2. Pomiar poziomu satysfakcji klienta za pomocą metody SERVQUAL na przykładzie branży ubezpieczeniowej

Źródło: Witkowska 2007.

Wyniki przeprowadzonego badania pozwoliły na przeprowadzenie zmian w sposobie utrzymania kontaktu z klientem. Badanie to zobrazowało, jakie cechy mają kluczowe znaczenie dla społeczeństwa - potencjalnych klientów towarzystw ubezpieczeniowych. Ocenie poddano także stopień pokrycia rzeczywistych dokonań pracowników z oczekiwaniami klientów. W przypadku branży ubezpieczeniowej, konieczne jest utrzymanie trwałych oraz budzących zaufanie relacji, przy zachowaniu możliwie najwyższego stopnia profesjonalizmu usługi ubezpieczeniowej. Wskazane w badaniu cechy powinny być zawsze oceniane w skali każdego pracownika z osobna oraz skali ogólnej - dopiero wówczas otrzymuje się informacje o skuteczności wybranego pracownika, a następnie obranej przez firmę strategii. Jeśli ta wymaga zmiany - badanie powinno wykazać możliwości i odpowiednie kanały rozwoju jednostki w przyszłości.

\section{PODSUMOWANIE}

Przeprowadzone badania zadowolenia/satysfakcji klienta jednoznacznie ukazują istotę problemu, z jakim na co dzień zmaga się rozwijające, nastawione na zysk i rozwój przedsiębiorstwo. Konieczne jest zwrócenie szczególnej uwagi na opinię konsumencką, płynącą z różnych kanałów przekazu oraz opracowanie metod optymalnego zmagania się z dysproporcjami (szczególnie informacyjnymi) w przedsiębiorstwie oraz kolejnych elementach łańcucha gospodarczego. Badanie satysfakcji klienta ma więc kolosalne znaczenie. Jego ocena umożliwia określenie, w którym momencie cyklu życia produktu znajduje się wyrób bądź usługa oraz umożliwia podejmowanie działań sprzyjających rozwojowi przedsiębiorstwa 
w przyszłości. Regularne podnoszenie jakości oferowanych produktów/usług przedstawia przedsiębiorstwo jako solidne, rzetelne i wysokie pod względem jakości oferowanych wyrobów, co przybliża kolejne jednostki do nabywania produktu konkretnego producenta.

\section{BIBLIOGRAFIA}

Ankiel M., Kuczyńska A., 2017, Wyznaczniki satysfakcji klientów korzystających z ustug medycyny estetycznej, „Studia Ekonomiczne. Zeszyty Naukowe Uniwersytetu Ekonomicznego w Katowicach", nr 330.

Błażewski S (red.), Ilustrowany słownik techniczny dla wszystkich, 1970, Wydawnictwo NaukowoTechniczne, Warszawa.

Frankowska J., 2011, Badanie stopnia zadowolenia klientów z jakości usług, Katedra Zarządzania i Prognozowania Bezpieczeństwem Zakład Zarządzania Kryzysowego, SGSP, Warszawa.

Hamrol A., Mantura W., 2006, Zarzadzanie jakością. Teoria i praktyka, Wydawnictwo Naukowe PWN, Warszawa.

Huczek M., 2013, Orientacja na klienta czynnikiem zapobiegania kryzysowi w przedsiębiorstwie, Krakowska Akademia im. A. Frycza Modrzewskiego w Krakowie, Kraków.

Iwasiewicz A., 1999, Zarządzanie jakościa, Wydawnictwo Naukowe PWN, Warszawa.

Krawczuk A., 2016, Wdrażanie systemu zarządzania jakościa wg ISO 9001, „Zeszyty Naukowe Uniwersytetu Przyrodniczo-Humanistycznego w Siedlcach. Seria: Administracja i Zarządzanie", nr 108.

Ostrowska K., 2004, System zarządzania jakościa zgodny z wymaganiami ISO 9001:2000 - o tym trzeba wiedzieć, [w:] E. Kreier, J. Łuczak (red.), ISO 9001 - Skuteczny sposób uzyskania certyfikatu jakości, rozdz. 1/1, Wydawnictwo Forum Sp. z o.o., Poznań.

PKN, 1996, Norma ISO 9001:1994, Systemy zapewnienia jakości - wymagania, Warszawa.

PKN, 2001, Norma ISO 9001:2000, Systemy zarzadzania jakościa - wymagania, Warszawa.

Quality management system - Requirements - Fith edition, 2015, https://dqs.pl/?uamfiletype=attachment\&uamgetfile=https://dqs.pl/wp-content/uploads/ISO9001_2015_PL_tlum.pdf [dostęp 28.06.2020].

Snarski P., 2012, Metody pomiaru satysfakcji klientów bankowych wykorzystywanych do analizy konkurencyjności banków, „Economy and Management”, vol. 2.

Witkowska J., 2007, Metoda Servqual w badaniach satysfakcji klientów ustug ubezpieczeniowych, „Problemy Jakości: Filozofia, nauka, jakość za granicą”, https://docplayer.pl/59842344-Metoda-servqual-w-badaniach-satysfakcji-klientow-uslug-ubezpieczeniowych-nauka-jakosc-zagranica.html [dostęp 30.11.2020].

[www1] https://arc.com.pl/Polacy-a-hejt-blog-pol-1552998539.html [dostęp 28.06.2020].

[www2] https://centrum.jakosci.pl/news,iso-publikuje-nowe-wydanie-standardu-iso-90012008.html [dostęp 28.06.2020].

[www3] https://dsc.kprm.gov.pl/sites/default/files/materialy_zarzadzanie_satysfakcja_klienta.pdf [dostęp 28.06.2020].

[www4] https://www.biostat.com.pl/uszczegolowienie-me-todologii-badania-satysfakcji-

klienta.php [dostęp 28.06.2020].

[www5] https://www.webankieta.pl/poradnik/metoda-servqual/ [dostęp 27.06.2020]. 


\title{
METHODS OF ASSESSING THE CONSUMER'S EFFECTIVENESS OF THEENTERPRISE'S ACTIVITIES - THE ASSESSMENT OF EFFICIENCY IN THE CONTEXT OF INNOVATIVE ENTERPRISES
}

\begin{abstract}
The consumer strives to own more and more by spending income obtained from various sources. This one wants more than less. Enterprises, wanting to meet the client's expectations, produce goods which determine the quality of the company's future financial results. When purchasing goods from a manufacturer, the customer expects the highest possible quality products, assuming an average price level, adjusted to his preferences and financial possibilities. There may be times when the customer is not satisfied with the service or product. This event has an adverse effect on the company. In order to optimize this phenomenon, it is necessary to take preventive measures, which are almost always preceded by thorough research and analysis. The following article will present the methods of obtaining information on the degree of customer satisfaction with the goods purchased by the author, selected by the author. Social and psychological arguments that affect the final level of customer satisfaction will be presented. The consequences for the enterprise, related to the results of the customer satisfaction survey, will also be indicated.
\end{abstract}

Keywords: quality, satisfaction, contentment, product, service, customer, method NPS, survey, survey, interview. 